Scientific Journal of October 6 University

ISSN (Print): 2314-8640

ISSN (Electronic): 2356-8119

Published by October 6 University @ All Rights Reserved

Available online at: http:// sjou.journals.ekb.eg

Case report
Sci.J. of Oct. 6 Univ. 2(2)296-305

Copyright: (C) 2014 Sally Michael Hanna. This is an open-access article distributed under the terms of the Creative Commons Attribution License, which permits unrestricted use, distribution, and reproduction in any medium, provided the original author and source are credited.

\title{
An Interview with Rita Dove
}

\section{Sally Michael Hanna}

\author{
Department of Foreign Languages, Faculty of Education, October 6 University
}

\section{Received: 25-03-2014/ Revised: 20-04-2014 / Accepted: 3-05-2014}

What follows is the script of a raw interview conducted by Sally Michael Hanna and Duccio Basosi with Rita Dove in Venice. I have been personally lucky to meet Rita Dove in Venice during Incroci di Civilta, the literary festival that has taken place in April 2014. I have Dr. Pia Masiero to thank for that, the chief organizer of the festival and my best friend and fellow academic for extending the invitation to me and to 6 October University to participate and for generously opening her home to me in Venice. Without her, this interview would not have been possible. It is worthy to note in this regard that I have read Rita Dove's work and have written extensively about all the poetry volumes she wrote. I have always found her work a source of inspiration in that she has given me a lot of food for thought, generous with both word and thought opening up worlds of myriad connections in which the impossible is only a step away. Hers is a comprehensive experience in which poetry courts all sorts of arts imaginable, music, paintings, dance and song. My meeting with Dove has confirmed one idea that selecting her as an author to read for a Ph.D was no coincidence but was rather a guided choice blessed by the love of the arts, the power of the word and the endless potential of imagination and the human mind.

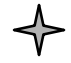

\section{A biography of Rita Dove as it appeared in the festival blurb:}

Human resources Rita Dove is a commonwealth professor of English at the University of Virginia in Charlottesville where she lives with her husband and daughter. Her collection Thomas and Beulah written in 1986 won a Pulitzer prize of poetry that makes her the second African American to win the prize. Dr. Dove has eight poetry volumes to her credit, please allow me to name them: The Yellow House around the Corner, Museum, Thomas and Beulah, Grace Notes, Mother Love, On the Bus with Rosa Parks, American Smooth and Sonata Mulattica. She also has one play, one novel and one short story collection to her credit. So when we talk about Rita Dove, she is not only a poet, there is a lot more to her work, there is narrative, dramatic work in her verse. in 1993 and for two years Dr. Dove is appointed to the term of poet laureate and a consultant of poetry to the library of congress that made her the youngest person and the first African American poet to receive the highest official honor in letters.

RD: Buongiorno. That is all the Italian I know. (Laughter and applause). First of all, I would like to thank everyone who made this possible. I think it is a wonderful conference, a wonderful celebration about the cross roads of civilization and culture. This presentation is perhaps going to be slightly different from what you have heard before because, as a poet, I have the luxury of talking between the poems in order to give you a sense of the wider spectrum of my work - where it has been and where it is going - rather than reading just one section from a prose book. So I will start with some fairly early poems from my second book, Museum; it is a museum that never speaks, the silent museum. These first two poems are actually set in Italy. The first poem is spoken by Boccaccio. I know I don't need to explain who Boccaccio is to an Italian audience; in America sometimes I do. The second poem is a companion piece in which Boccacio's lover Fiammetta takes a decidedly cooler view.

\section{Boccaccio: The Plague Years}

Even at night the air rang and rang.

Through the thick swirled glass he watched the priests sweep the past in their peaked hoods, collecting death.

On each stoop a dish burning sweet clotted smoke. He closed his eyes to hear the slap of flesh onto 
flesh, a liquid crack like a grape as it breaks on the tongue.

As a boy he had slipped

aong the streets, in love with he didn't know whom. $\mathrm{O}$ the reeded sonatinas and torch flick on the chill slick sides of the bridge and steam rising in plumes from the slaughterhouse vents-twenty years.

Rolling out of the light

He leaned his cheek against the rows of bound leather: cool water. Fiammetta!

He had described her a hundred ways; each time she had proven unfaithful. If only he could crack this city in two so the moon would scour the wormed streets clean! Or walk away from it all, simply falling in love again. ... (Museum, in Selected Poems, 82)

\section{Fiammetta Breaks her Peace}

I've watched them, mother, and I know the signs. The first day, rigor. Staggering like drunks, they ram the room's sharp edges with the most delicate bodily parts and feel no pain. Unable to sleep, they shiver beneath all the quilts in the house, panic gnawing a silver path to the brain.

Day two is fever, the bright stream clogged, eyes rodent red. No one weeps anymore; just waits, for appear they must - in the armpits, at the groinhard, blackened apples.

Then, at least, there is certainty, an odd kind of relief; a cross comes on the door.

A few worthy citizens gather possessions around them and spend time with fine foods, wine and music behind closed drapes. Having left the world already, they are surprised when the world finds them again.

Still others carouse from tavern to tavern, doing exactly as they please. . .

And to think he wanted me beautiful! To be his fresh air and my breasts two soft spiced promises. Stand still, he said once, and let me admire you.

All is infection, mother- and avarice, and self pity, and fear!

We shall sit quietly in this room, and I think we'll be spared. (Museum, in Selected Poems, 82)

RD: Before I go on, I would like to thank the people who are responsible for these excellent translations: Stefania Bassete, who is a student here at the university, and Roberto Ranieri who looked over her translations and said they were wonderful. As I was saying to Stefania before this began, I could tell by the questions she had written in the margins that she was on the right track, and I was really pleased to see that level of insight.
This next poem is from On the Bus with Rosa Parks; we will be discussing that book later:

\section{Dawn Revisited}

Imagine you wake up

With s second chance: The blue jay

Hawks his pretty wares

And the oak still stands, spreading glorious shade. If you don't look back, the future never happens.

How good to rise in sunlight, in the prodigal smell of biscuits- eggs and sausage on the grill.

The whole sky is yours to write on, blown open to a blank page. Come on, shake a leg! You'll never know who's down there, frying those eggs, if you don't get up and see (On the Bus with Rosa Parks 36).

RD: I have written several books containing poetic sequences. I think the best way to describe them is that each poem is like a pearl on a necklace - each can stand alone but may shine brighter next to its neighbor, and strung together, they tell a story. My most recent book, Sonata Mulattica, is a poetic sequence reflecting on the life of an actual character from history: George Polgreen Bridge tower, a mixed-race violin prodigy born in 1780; his mother was of Middle European extraction and his father called himself an African Prince. George Bridge tower's claim to fame is that Beethoven composed a sonata for him, which they premiered together in 1803. Yet somehow this miraculous event had slipped between the cracks of history. The realization that I, an African-American who almost became a classical musician, knew next-tonothing about this amazing musician started me on a quest that resulted in this poetic journey. The poem I will read next occurs near the end of the book and is from Beethoven's point of view. As you know, Beethoven left his native Germany to settle in Vienna, where he spent the rest of his life.

\section{The Composer's Coda}

I wanted fame. I wanted love.

I deserved bliss but bliss scares easily.

I fled Bonn's dreary terrain for Vienna's grave lilt: There I learned to cherish even the gaps, the static.

Fame became moot.

Love, a strategy.

Beauty was what I couldn't seem to hang on to. Beauty would discharge her blandishments, then retreat to observe the effect.

Now I know none of this is real, none of this exists. 
That next moment, shimmering before you? Wink - and it will either astonish you or be gone. (Sonata Mulattica, 203)

And the final poem I'll read is $\boldsymbol{T a} \boldsymbol{T a}$ Cha Cha. I chose it because it takes place on St. Marks Square right here in Venice, and the weather in this poem is about the same as today's - it's almost about to rain. And though there are a few more tourists in this poem than you'll find at this time of year, just wait a month and they'll be there! In the poem I am actually a tourist, surrounded by tourists. I like to stand back and watch, at the edge of things; I love watching the pigeons navigate foot traffic. True to its title, the poem imitates the rhythms of a cha cha.

\section{Ta Ta Cha Cha}

One, two - no, five doves scatter before a wingtip's distracted tread:

Lost, lost, they coo, and they're probably right:

It's Venice, I'm American, besandaled and backpacked, sunk in a bowl of sky trimmed with marbled statuary (slate, snow, ash)-

a dazed array, dipped in the moon's cold palette.

Who, you? No. But here, lost from a wing, drifts one pale, italicized answer. I pick it up as the bold shoe continues conversation (one two) with its mate, and the nearest scavenger skips three times to the side, bobs to pluck his crackerjack prize, a child's dropped gelato cone.

Tip, tap: early warning code for afternoon rain. Gray vagabond, buffoon messenger for grounded lovers-where to?

Teach me this dance you make, snatching a sweet from the path of a man who, because he knows where he's headed, walks without seeing, face hidden by a dirty wingspan of the daily news. (American Smooth, 2011)

SM: I am honored to be among you here today and before we continue with the beautiful poetry, I would love to share with you a biography of Dr. Rita Dove. Dr. Dove is a commonwealth professor of English at the University of Virginia in Charlottesville where she lives with her husband and daughter. Her collection Thomas and Beulah written in 1986 won a Pulitzer prize of poetry that makes her the second African American to win the prize. Dr. Dove has eight poetry volumes to her credit, please allow me to name them: The Yellow House around the Corner, Museum, Thomas and Beulah, Grace Notes, Mother Love, On the Bus with Rosa Parks, American Smooth and Sonata Mulattica. She also has one play, one novel and one short story collection to her credit. So when we talk about Rita Dove, she is not only a poet, there is a lot more to her work, there is narrative, dramatic work in her verse. in 1993 and for two years Dr. Dove is appointed to the term of poet laureate and a consultant of poetry to the library of congress that made her the youngest person and the first African American poet to receive the highest official honor in letters. Please join me in welcoming Dr. Rita Dove.

\section{Interview:}

SM: I was first introduced to you on a felucca in the Nile in 1999. A felucca is like the water taxi here in Venice, only that it is for entertainment purposes so I used to go with my friends on felucca rides to read poetry and eat Pizza. I was a $\mathrm{Ph}$. D student at the time and I was trying to research an author for my $\mathrm{Ph}$. D thesis. I was simply trying to share my vision of the kind of poetry that I would like to read and I defined that poetry as "poetry that takes wing" when suddenly one of my friends said read Dove and the whole Felucca laughed because we were not sure about the kind of energy that was created with wings and Dove. Speaking of names, I always believed that naming is framing. Has your name had any kind of impact on the poetry you write?

RD: (laughter). We grow into our names. We grow around our names, we try to make sense of our names. I think every child sits and contemplates their name, trying to build an identity, so of course my name had an impact on me. First of all, I knew from a very young age that the Rita stood for Rita Hayworth; my mother loved Rita Hayworth's sassiness and watched her movies when she was pregnant. Dove actually comes from Cherokee; my father was born in Georgia and has a noticeable percentage of Indian blood; there are Caucasian Doves and Black Doves in Georgia, all with a bit of Cherokee in them. I felt lucky to have such a beautiful name. I am sure my attraction to the pigeons in St. Mark's Square had something to do with my name. And I actually slip the word "dove" into every book, just for the heck of it! I believe one of the major differences in the music of poetry and the language of newspapers is that poetry takes wing; even though poetry may deal with smaller topics, it can escape the strings of language and lift off the page. I tell my students (I teach at the University of Virginia) that when you're writing poetry, silence becomes your companion. You are using the words to get at the silence behind the words, and to achieve that is another kind of lift off.

SM: I think birds show up a lot in your work as you said but I was wondering about the symbolic level of those birds. Are these birds of escape or birds of flight?

RD: Both (laughter). Both, in the sense that a bird has to fly, yet ultimately there is no escape from the world. I don't like to define it as escape: One lifts 
off in order to get the lay of the land, after all. But I always come back, and I don't really consider it a return to a prison. It's just what it is. As a child, I was impressed by the biblical tale of Noah sending the dove out three times to see if the waters had receded and the land was inhabitable; I was actually distressed the third time when the dove did not return. How could you leave your home without even looking back? I would be the dove who took a trip around the perimeter and came back to tell the others.

SM: You have toyed brilliantly, I believe, with many forms, namely villanelles, sestinas, Sonatas and sonnets. Do you think that poems choose their forms? How do you go about selecting a form for a poem?

RD: I never select a form. The form selects me; it's a matter of listening to what kind of dance I'm going to have to make between language and silence. For instance, I have a poem called "Parsley" which takes places in the Dominican Republic during Trujillo's execution of Haitian cane workers in 1937. Trujillo had each one of the cane workers speak the Spanish word for parsley, "perejil", and those who could not roll their rs were slaughtered. When the Haitians spoke, the " $R$ " in "perejil" came out as an "L". This was Trujillo's way of making them pronounce their own death sentences: 20,000 slaughtered in a single day! How to convey this horror? The villanelle, with its recurring lines, seemed ideally suited for emulating the drum beat of that word "perejil", spoken over and over and over again. As a verse form, the villanelle keeps turning back on itself; you can never escape it. How form emerges is a rather mysterious process for me, but I can say with certainty that form always chooses itself. In my book Mother Love, the predominant form is the sonnet. Since the book draws upon the myth of Persephone and Demeter and is all about mother daughter relationships, it seemed like a no-brainer to use the sonnet form.

DB: When the organizers asked me to participate in this conversation, I was thrilled and then after five minutes, I realized as a historian - what I would be able to ask and how I will be able to perform in this conversation. I will not pretend that I am a great expert of poetry and I will do my job as a historian. So since we are talking about form, this brings me to my first question. Aristotle in book IX of The Poetics speaks about the difference between the poet and the historian and that the difference is not in the fact that one writes prose and the other writes verse. He says that the true difference is that "the historian relates what has happened while the poet what may happen. Poetry is more philosophical and more elevated than history, since poetry states more universal things whereas history states particular things." In an interview which I found preparing this conversation, you said that poets struggle to render into words that which is unsayable. So my question is: are we historians condemned to permanent inferiority? (Laughter) RD: These are different ways of looking at the same thing. You are not condemned to inferiority! For instance, without history and the historian, I would not have known about Trujillo for my poem "Parsley". Although there was very little research on George Polgreen Bridge tower, knowing the broad facts of what happened centuries ago made it possible for me to imagine what this violinist's life might have been like - how he thought, what he felt, what it would have been like to look out of his eyes. So history comes alive. It's more of a symbiotic relationship, an attitude which probably comes from being an African American woman living in a world which is not calibrated to my background and therefore doesn't accommodate my view. Even as a child I knew there were at least two different ways of looking at the world. I would fit myself into the mainstream every morning before going to school -its rhythms, dress code, and beauty standards - and on weekends I was part of the African American community. It was completely normal for me and my cousins to switch the way we talked, depending on who was listening. We knew the game could change simply by walking from one room into the next -suddenly the music could be different, the body language and behavioral protocol. As soon as I was old enough to be aware of the world, I understood the "official" story as well as the view from the sidelines. I always thought of this as an advantage rather than a disadvantage. The black historian W.E.B. Dubois writes about the kind of binocular vision one acquires when one is not a part of the mainstream it's the ability to see things three dimensionally because you can take in the prevailing point of view while maintaining the revisionist view from the margins. I have always been aware that for every story deemed important and true by historians, there were a thousand others that would never make it into the history books. Obviously we can't put every event in the textbooks, yet just as obvious is that realization that every minute we live matters to us. All which disappears - that's what interests me as a poet. So please, continue to take care of the big stuff in history, and I'll take care of the little stuff.

\section{DB: Thank you.}

SM: Speaking of history, you have always been referred to in almost all the interviews as the historian of the everyday because as you just said, you always look at the underside of the grand historical events. Is this your way of personalizing the grand narrative of history? 
RD: I don't think of it quite that way. I'm not personalizing history; rather, I'm saying: This is another history. Let me give you an example: When I began work on Sonata Mulattica, I didn't approach the story of George Bridge tower from the outside. I didn't think: What an interesting historical character; let's see if I can give him flesh! No, I wanted to get to know him personally; and though I began researching like a historian, I soon began searching for details that would help me imagine what it would be like to walk the streets of London in 1790 as a little dark-skinned boy with a violin tucked under his arm. The end effect may appear to be a personalization of the grand historical narrative, but the very nature of poetry is to confound the notion that you can stand back and look at what's happening; with poetry, you are put deep in the thick of things. It's one of the reasons I don't stick to a BBC British diction in these poems; instead, the language is sometimes down-to-earth, sometimes elevated, and sometimes contemporary; there's even a farce in the middle of the book, a bawdy little skit with girls singing Doowap like The Supremes! Poetry is not decoration; it is an intense, distilled way of apprehending and living truth.

SM: On the Bus with Rosa Parks is one of the most contested volumes that you have ever written. I read the volume as a tribute to Rosa Parks, a simple seamstress, who by simply doing nothing had helped ignite the Civil Rights Movement. I was just wondering about your choice of keeping the Rosa Parks poems to the end of the volume and how does this answer to the way you look back to the past?

RD: It is true that even though the book is called On the Bus with Rosa Parks, the Rosa Parks poems are placed three quarters of the way through the book. This was a very deliberate decision on my part. It's so easy to have one's race or one's difference relegated to a pigeonhole, particularly in the US. One becomes an African American Poet, a Woman Poet, an Asian American Poet, and is safely tucked away under that label. And since professionals may not feel compelled to read outside of their discipline, they don't feel guilty if these "specialty poets" don't make it onto their syllabi. The danger inherent in any kind of label is the subconscious filter it provides to see through; interpretations become based on preconceptions, what we think we know already. I was concerned that the reader would see the name "Rosa Parks" and all the images of the Civil Rights Movement police dogs, fire hoses, lynch mobs - would immediately come to mind. I wanted my reader to see these brave people as entire and complete human beings with ordinary problems, like having blisters from their shoes, or dreaming of getting home from work or needing a cup of coffee. I put those poems at the end of the book so that by the time you get to them, your antennae are attuned to the detailed intensity of poetry, not some vague idea social injustice. This sequence also contains poems about other women just as brave as Rosa Parks, black women who refused to give up their bus seats and were jailed but didn't make the history books because they were not politically expedient. I'd like to read another very small poem, called simply "Rosa":

\section{Rosa}

How she sat there, the time right inside a place so wrong it was ready.

That trim name with its dream of a bench to rest on. Her sensible coat.

Doing nothing was the doing: the clean flame of her gaze carved by a camera flash.

How she stood up when they bent down to retrieve her purse. That courtesy. (On the Bus with Rosa Parks 83).

RD: Rosa Parks was chosen to serve as the test case for desegregating the buses in Montgomery, Alabama. A major factor in the selection was her appearance: she looked so unassuming, so petite and proper, that the NAACP decided she would be unassailable; no one could cast aspersion on her. And in fact, five days after her arrest when she went in for her court date, one woman yelled out from the crowd, "Oh look at her - ain't she sweet? Boy, they're in trouble now." There were several other women who had been arrested before Rosa Parks, for the same act: One had had a child out of wedlock, so the NAACP knew her reputation would have come under attack; another didn't have a good enough job so was of questionable socioeconomic status. It was complicated. In a way, I was exercising a similar type of caution in my book, building the poems so that one could look at everything that happens in the book through a humanitarian lens, and not with an agenda.

SM: Rosa is a beautiful minimalist poem. I think you are the kind of poet who knows how to functionalize silences. I would like to go back to Dawn Revisited and I would borrow the line: "If you do not look back, the future never happens." How do you perceive of time both artistically and personally?

RD: Well, if you aren't able to look back at your past, the future will not have a shape; you'll simply stumble into it. At the same time, as the poem says, you must gather the courage to plunge into the future: "You'll never know / who's down there, 
frying those eggs" unless you go see. You'll never get anywhere if you don't try. Whenever I write a poem, there is exactly that kind of push and pull. If I am not surprised during the act of creation, I know the poem is not going to be any good. Not being surprised means knowing exactly where I am going, it means I'm exploring old territory, which will be boring to the reader, too. Surprise means discovery. Writing is a terrifying act, but it is also exhilarating; one writes when haunted enough - by an event, a character, an image, a mood - to sit down and describe it; even an historical event, where the actions are known, can hold secrets. I began the Rosa Parks poems thanks to my daughter, who was around 12 at the time. (She is now 31). She and my husband had accompanied me to a conference for high school students at which various luminaries from different professions -writers, actors, Nobel laureates, movie directors, and politicians - gave off-the-cuff talks and advice. Rosa Parks was also there. We were taken in buses from venue to venue, and one time we boarded one of the buses and Rosa Parks was sitting in the front row. As we shuffled past my daughter leaned over and whispered: "We're on the bus with Rosa Parks!" It was a perfectly iambic line; I heard the music of it and the wonder in her voice, so I wrote her comment down in my note book. That's how the book started: What does it mean to be on the bus with Rosa Parks, and all the permutations of that query. But I had no idea where I was going to end up.

DB: I have a question about Rosa in the sense that it struck me because it is beautiful. You tell us very little about this person. We know it is a she and that she has a sensible coat, and that she was sitting and that doing nothing was the doing. We know it is a "she" and that she has a sensible coat, and that she was sitting and that "doing nothing was the doing." We know that it is Rosa Parks and we know that there is a lot of history condensed here but you do not tell us that it is Rosa Parks we are reading about. Then what struck me was that you used the term "dream" and if I think of Rosa Parks, I think of the Civil Rights Movement, the word dream then comes to my mind for the speech of Martin Luther King, I have a dream. But while the dream of Martin Luther King was magniloquent, the dream of Rosa is the dream of a bench to rest on. So If I put the two things together, I know we should not ask poets what they meant to say but are you kind of telling us that we should not look at these figures as heroes? That they have to be humanized? Are you telling us that more or less, all women could be Rosa Parks? That there is a human face behind the heroism?

RD: I think your analysis is very good; you picked up on all sympathetic strings that can be struck in the poem. Of course, we should look at these figures as heroes, but we should also remember that they are human beings. The question of what is it like to be on the bus with Rosa Parks is the idea of putting ourselves in her position and contemplating what we have done in that moment. What perfect storm had to occur for that moment to take place? Many acts of heroism come down to an intimate, very ordinary turning point, such as sitting on a forbidden bench because your shoes pinch, or drinking from the "Whites only" fountain when you're thirsty and there's no other fountain around, or wanting to sit at a lunch counter and be served because that's what teenagers do on television sitcoms. These moments grow into something grand and almost unfathomable in terms of heroism, but in the end it all boils down to wanting someone to look you in the eye and treat you as a human being. The poet strives for the universal by going through detail, always detail. The word "dream" sounds like a very big word, especially when you think of Dr. Martin Luther King, but it can also be hoping to find a bench to sit on. And speaking of names: A name like Rosa Parks is a very concise nugget of language containing a cosmos of emotional resonances - the sweetness of the rose and its thorns, the park as a place of refuge. We have mythologized so many of the heroes of the Civil Rights Movement, which makes it very difficult to get past the headlines and see Rosa Parks as a human being. Instead of trying to fill in her entire life, which would have been presumptuous, I chose to make her an Everywoman, any woman who just wants to rest for a moment. Still, we know Rosa Parks as a symbol, too. My task was to capture the impenetrability of the camera flash while revealing the human being inside the moment, coming home from work, who just wants a little bit of quiet. Don't we all?

DB: I catch up here to bring you farther away from poetry. Again as I was preparing for this conversation, I read that you are the second AfroAmerican poet to win the Pulitzer prize and the first Poet Laureate and Consultant to the Library of Congress. And I started to think that you are not defined the first person from Akron Ohio to win the Pulitzer prize or the first tango dancer to win it (laughter) so basically the question is what is your take on the color line in the age of Obama?

RD: Just a little question! (laughter) I would hope there would come a day when a biographer would not immediately use labels such as "the first African American." Of course, that's rather disingenuous, because why not acknowledge the obvious? I would say fine, as long as we see the entire person. To claim that we are in a color blind society is idiotic. We have a long way to go, and 
not to acknowledge that someone comes from a distinct heritage can cause as much damage as dwelling on it; it really depends on how you bring it to the table. I have been in so many conversations where someone will say, "Oh you'll love Mariflo, she's from Alabama," and after trying to figure out why I, of all people, would have a rapport with Mariflo, I'll ask, "Is she white or black?" because I can tell they're talking all around what they consider the key element in our potential friendship. People are shy about pointing about race because they want to be politically correct. All sorts of awkwardness arise from the fact that we are not comfortable with acknowledging difference. I think that we are making great strides, and I am resigned to being labelled. What I find it shameful is that I am only the second black poet to win a Pulitzer Prize. Someday, I hope, our numbers will be so great that biographers will merely say "Pulitzer prize winner". Someday I hope someone comes along who won't find it necessary to say she writes about being an African American but will simply call her subject matter "humanity". I write about being human in this world - sometimes as an African American, sometimes as a woman, sometimes as a tango dancer. Do not ignore part of my humanity so that you can fit me into an easy bracket. What's difficult to understand for someone who doesn't belong to a marginalized group are the assumptions that confront one when you leave the marginalized community and enter the world. The experience of walking into a room where no one looks up and thinks "oh she's different" is an unconscious luxury, not having to prove to strangers that there's common ground between you. That's the way it is always going to be, perhaps; I only ask that when I enter a room, my race will not be the only thing seen, that you will hear the true me when I speak.

SM: You have always been discreet about expressing racial indignation, there is always anger there, but it is a different kind of anger, a neutralized anger that you have definitely dealt with. I would like to know your take on that. How do you deal with anger both on a personal and on a poetic level?

RD: Wow, we're going deep now! First of all, you have to understand the context of the times. My generation fell in between Martin Luther King, the Civil Rights Movement and the Black Power Movement. I was too young to attend the March on Washington - I was eleven - but my father did. During the Black Power Movement in the sixties, I was just entering high school; though I read the poems of Sonia Sanchez and Amiri Baraka, I did not really need them until later in my life. Let's go back even further: When I was a toddler, my father became the first African American chemist in the rubber industry in Akron, Ohio, yet I didn't know anything about his struggle until I was in high school; I had no idea that he had operated the elevator at Goodyear Tire \& Rubber Company, ferrying his former classmates to the jobs he had helped them get because he had been a tutor for Organic Chemistry in college. Up and down in that elevator for years before he finally broke through the racial barrier. Later when I asked him, "Why did you keep this from us?" he replied: "I didn't want you to become bitter. Bitterness is a dead end street; I wanted you to feel, for as long as possible, that you could do anything." That was what his generation did for us. The idea that bitterness is a dead end street became a mantra for me: If I shout, people will hold their ears; if I whisper, they have to lean in and listen. So you're right: The anger was there, is there. But I do not shout it.

SM: Ok, I will take you from the deep waters into writing. I understand that you mentioned that writing is a difficult process. Do you start from a conscious or an unconscious plane of recognition? How do these seeds germinate? And what comes first? Is the word more attractive than the cadence because when I read you I listen to music, I enjoy the moves, I feel the dance, aside from American Smooth your poetry dances and sings and plays all sorts of music. I was wondering about your take on this.

RD: I would say that the word is the music and the music is the word. They are not separable in my mind. Language comes first for me. I can hear a phrase or a word as if it were a foreign tongue; I hear the musical cascade of syllables, the clicks and sighs of consonants and vowels. As a poet, I proceed by language, and the story takes care of itself. I am responsible for the way the story is told. I believe a poem has to sing. I grew up with music; I started studying the cello at the age of ten, and in later years I also began playing the bass viola de gamba. When I realized I couldn't lug this huge instrument along on my reading tours, I started taking voice lessons so I would carry the music inside me. Later my husband and I took up ballroom dance. I must have music in my life, and language is yet another way of having music. For me, the poem begins with the way it sounds. Often I will start a poem in the middle of the page; I can even sense where a word belongs in a line I haven't yet written; I put it in place on the page and wait for the rest of the poem to gather round it. I have a strange way of composing: I tend to work on many poems simultaneously, so I'll write little fragments, then store them in color-coded folders to keep the organization on an unconscious level- not the level of intellect and discourse, but deeper. Poetry can control the very way in which the reader breathes, so if the reader is breathing with the 
poem, he has already entered the world of the poem. I am orchestrating language in order to provoke an emotion, and that work has to happen on a deeper level. I try to make sure the music of language is ever present, that each word is drenched in it.

SM: You say that poets do not fit certain categories. How different is the space that you occupy as a poet?

$\mathrm{RD}$ : This is an interesting question. I don't believe in the great divide some people claim exists between prose writers and poets and dramatists. We are all dealing with language on an intimate level; it's just that we have different pulses, so to speak. I know poets who think prose writers are somehow lesser beings. Nonsense! All serious writing is difficult; we are all trying to put into words what is ineffable, so that the reader can experience that wordless moment. What poetry does differently from prose goes back to Aristotle's definition of the historian and the poet: The poet stops in time so you can dwell in that instant contemplating as life and time continue to flow around you - like standing at a well and looking down into it while others walk around you, chatting and gathering water. Whether you are reading or writing the poem or if you are writing the poem, this is the cherished relationship between reader and poet: You feel as if you are standing still as time moves around you; even if you're talking to someone next to you. This disconnect is profoundly felt in poetry. The feeling is different when I write stories or even drama, because prose moves through time; there is a narrative, and that narrative moves through time. So you can decide to open a novel and either dive into its temporal stream or stay on shore; whereas a poem tends to ambush you and snatch you out of the busy world. You might feel distracted and a bit disconcerted, but in a good way.

DB: I would like to ask you something about another word that often occurs in your writing which is the word freedom. Of course, we know that freedom is quite a crucial word in the United States from the Declaration of Independence onwards and possibly further down. As a historian, as I think of the word freedom in the terms of Eric Foner, story of American liberty and his learned explanation of how freedom in the United States isn't a set of enlarging circles. It is not the same freedom that actually reaches more and more people but in reality what happens through 200 years of US history is that freedom changes substantially. The freedom to own slaves, the freedom to treat women as commodities is not freedom that we know after abolishing slavery, after the movement for women rights and so that is one point. The other is Janis Joplin's definition of freedom as just another word for nothing to lose. What is your take on this crucial point?

RD: Like any word - every writer knows this - any word can be turned on its head to mean its opposite. The United States has invented its own brand of freedom. I'm not a historian, so I won't get into this too deeply except to say that I have always been intrigued by the sense of individualism that imprints the United States' concept of freedom. USA believes in freedom as an individual right; taken to its extreme, this belief can lead us into murky waters, such as demanding the freedom to treat someone badly or using the First Amendment to justify hate speech. There's also the sense of freedom inspired by North America's geographical latitudes; historically, if you didn't feel free where you were, you simply packed up and went west, west, west until you hit the Pacific coast and landed in Los Angeles, America's Dream Park - and that's worth a whole other discussion! Freedom has never been a fixed point in the United States, so I weight any definition of the word with many grains of salt. I cannot simply define freedom as being able to do whatever you want, since every action depends on how everybody else acts as well. You can be free to walk the streets, but if someone is going to lob insults - or worse - at you, you are not free. You are free to think whatever thoughts you like, but in a society where censorship and oppression are the rule, the mind becomes its own kind of prison. For me freedom is more private. I want the freedom to be able to think without running up against social impediments, which is harder than you might imagine. Let me think of a poem of mine that talks about freedom. Ah, I have one! It's called Pastoral, and I'll just read the last few lines. A young mother is breast feeding; she looks down at her infant and says: "I felt then / what a young man must feel / with his first love asleep on his breast: / desire, and the freedom to imagine it." Now, you might think that act of breastfeeding is all about dependency, yet the ability to generate food for one's child engenders an incredible sense of independence. At the same time the mother feels beholden to this tiny creature - but that is also an odd kind of freedom, just as the love connecting them is rooted in sexual desire. In the poem, the mother has a flash of insight and understands the tender strength the man feels as he looks down at his lover asleep in his arms -strength that comes from trust, and the wonder of the world spread out before them, how he can look up and imagine the future. As a poet, I can love the world and still have the freedom to imagine this love. That is the best thing of all.

SM: Allow me to take you back to the world of music and Sonata Mulattica, which is one of my favorite volumes. I think the book is a tribute to the 
worlds of both poetry and music as it pieces together the story of a man whose life was later shattered by race selectivity. In the volume you state: "this is a story about music and what it does to those who make it, whom it enslaves. Yes, slavery of all kinds enters into the mix." I think that the volume answers the question "how does a shadow shine? How was the idea of the volume conceived?

RD: It was one of those wonderfully serendipitous moments. I just finished my book American Smooth and sent it off to the publishers, and I thought I would take a breather for a month or two. One evening my husband and I sat down to watch a movie called Immortal Beloved. As a biography of Beethoven, it was a pretty good film - not great art, but interesting entertainment. So we were pretty relaxed when a scene flashed on the screen in which Beethoven walks through a group of musicians in Vienna who are all clamoring to play for him. Beethoven is going deaf but has told no one; trapped in his own agony, he makes his way through the crowd. Among the musicians is a black man holding a violin. So while Beethoven disappears into another room to lean his head on the piano so he can feel the vibrations, my husband and I look at each other and say, "We've heard of blind casting but this is a bit extreme!" After the movie I went online, typed in "black violinist Beethoven" - there was one entry, a short paragraph on George Bridge tower. So began my quest, but I wasn't thinking about writing poems I just wanted to know more about him. In a way, I was ashamed: as a classical musician and an African-American, I felt that I should have known about him. I began piecing together the precious few facts I could find, gradually realizing that I had labored under the assumption that I could identify with him because we were both black. But he was Afro- European, with a white mother and an African father; he was a prodigy already concertizing at the age of ten. As I got deeper and deeper into the research, I understood that I was applying American standards to his world; in short, I was colonizing him. So I had to strip away all my preconceptions and enter his life with open eyes. When I found out that the sonata Beethoven had composed for him was named after another (white) violinist, I leapt to the conclusion that it was because Bridge tower was black. Then I discovered it was because they had argued over a girl to whom Bridge tower had made a "saucy" comment -which then led me to wonder just what the relationship was like between these two men? It turns out they were great friends for about three months; even though Beethoven was going deaf, he so loved Bridge tower's playing that he dropped everything else in order to compose for him a piece so difficult, other violinists - including Rudolf
Kreuzer, the eventual dedicatee - declared it unplayable! By freeing myself of contemporary racial attitudes, I was able to understand how profound the affection was between them, and how in sync they were musically. Bridge tower premiered the sonata with Beethoven at the piano; since Bridge tower had been described as a very "extravagant" performer, Beethoven could actually watch him play and catch the beat. So there was almost a physical connection between them. I began to comprehend what it meant to be darkskinned in a Europe that had already stopped its slave trade yet still craved novelty. Bridge tower spent most of his life in London, where the curse of always standing out was at odds with capitalizing on that novelty; this became part of his story. He was sought after as a violinist and led a charmed life as a musician, moving in the highest cultural circles, yet he was a novelty, too. There was always that. He knew how to use his difference, but it also imprisoned him.

SM: Is Bridge tower Langston Hughes' banished prince or is he the reinstated crowned prince? I find it quite curious that you create a language of entrapment around him? Especially the way you physically describe him even toward the end of the volume when you tell him:

Will I cry for your Polgreen? Will I drag out your end?

Though it is long past, though I drove slowly past The place of your dying days and recorded What I knew I'd find there?

And finally you ask the question:

Do I care enough, George Augustus Bridge tower, To miss you? I don't even know if I really like you. I don't know if your playing is truly gorgeous or if it was just you, the sheer miracle of all That darkness swaying close enough to touch, palm tree and Sambo and glistening tiger running circles into golden oil. Ah, Master B, little great man, tell me: How does a shadow shine? (Sonata Mulattica 208)

RD: Yes; because in the end, one of the biggest problems with trying to inhabit a color blind society - "blind" is a perfect word for it! - is that identity cannot be reduced so simply. Everything about humanity is complicated, and that is a good thing. Just because there's this mixed race violinist who disappears from history - just because the prodigy turns out to be half African - doesn't necessarily mean that he was a wonderful human being; oppression does not automatically make him a hero. I kept running up against the uncomfortable suspicion that he was a chauvinist as well. Of course, everybody was a chauvinist back then; it was a man's world, after all. The poems of Sonata Mulattica are overwhelmingly male oriented- I 
think there are only three women who speak in the entire book - because that was the world he moved through. Hence my admission in the last poem: "I don't even know if I really like you." I felt I had finally gotten close enough to him to say. "Hey, I don't know if we would been friends." That, to me, was a moment of freedom: I had gotten past the labels - look, a great musician, a mixed race prodigy! - to see him a flawed human being. Could we have even talked?

SM: Thank you so much for a wonderful conversation with Rita Dove and Duccio Basosi. I also thank members of the audience for their participation.

Works Cited:

Dove, Rita. "Interview with Rita Dove." Incroci di Civilta, Venice, Italy.

https://www.youtube.com/watch?v=nYBpRgUBK G8 Published Apr 7, 2014 by Fred Viebahn. Retrieved August 28, 2014. 